\title{
The Impact of Female Education on Economic Growth: Evidence from Egypt and Jordan
}

Amany Y. Gad

This study aims to examine the effect of female education on economic growth in Egypt and Jordan by constructing six panel data models during the period from 1980 to 2016: three "total" panel models and three "female" panel models. By subdividing education levels into primary, secondary, and higher, it can examine the effect of different education levels on economic growth. This study uses ordinary least squares (OLS) technique. The positive impact of higher and primary education enrollment rate is significant; however, the secondary education enrollment rate in both the "total" and the "female" panel models does not have a significant impact on economic growth. Also, the results indicate that both the total labor force participation rate as well as female labor force participation rate has the most significant positive impact on economic growth, while fertility rate has a significant negative impact on economic growth.

Keywords: economic growth, female education, higher education, ordinary least squares, primary education, secondary education

\section{Introduction}

Education is a fundamental human right and a basic requirement for human development in the society. It is also very important for the development of any country and offers wide-ranging benefits to both individuals and societies. Education is a key factor in empowering people and developing the economic, social, and personal well-being of all citizens in a society, as well as to compete within the global market.

"The Education for All" initiative is a global commitment to provide quality basic education for all children, youth, and adults. This initiative was launched

Amany Y. Gad, Assistant Professor, Faculty of Business Administration, Economics and Information Systems, Misr University for Science \& Technology (MUST), Egypt, amanygad@, yahoo.com; amany.gad@must.edu.eg

(C) 2020 International Consortium for Social Development 
at the "World Conference on Education for All" in 1990. It affirmed a commitment to achieving education for all, especially universal primary education by 2015 .

Education is the responsibility of the state and the government who should make every possible effort to provide it on an ever increasing scale in accordance with the national resources. The community should also realize its role in the development of education (Rahman \& Salah, 2009).

Economists have given due importance to the concept of human capital, which includes education, labor force, health, training, and a number of other factors (Lucas, 1988), which, in turn, accounts for the economic growth of a country. This is especially evident in the writings of Schultz (1961) and Becker (1962). Thus, investing in education is considered as the main pillar and a vital instrument for achieving sustainable economic growth over time.

Education is necessary for individuals and societies. Individuals and societies with high levels of education may have a high level of income than individuals and societies with low levels of education. It can be concluded that education is essential for economic growth, for enhancing earnings at private and public levels, and for empowering and developing the productivity of the individual and the society as a whole (Schultz, 1961).

Barro (2001) concluded that the schooling variable was positive and highly significant in economic growth using panel data of around 100 countries observed from 1965 to 1995 . The growth is positively related to the level of average years of school attainment of males at secondary and higher education levels. However, school attainment of females at secondary and higher levels has not affected economic growth because highly educated women are not well utilized in labor markets. Another study conducted by Gyimah-Brempong, Paddison, and Mitiku (2006) found that all levels of education had positive and statistically significant effect on the growth rate of per capita income in African countries during 1960-2000.

A significant amount of literature is also available on this topic in Pakistan. Most of the studies measure human capital by using enrollment rate at primary, secondary, and tertiary levels as its proxy indicators.

- Abbas and Foreman-Peck (2008) have examined the relationship between human capital and economic growth using time series data from 1960 to 2003. Their main finding is that human capital accounted for about 40 percent increase in gross domestic product (GDP) with an increase of 1 percent human capital. Therefore, they have suggested that low investment in education may be one of the main reasons for low economic growth. Thus, it has been concluded that the higher the level of education of the population, the fewer will be the number of poor individuals.

- Afzal, Farooq, Ahmed, and Begum (2010) examined the relationship between enrollment in school education and economic growth for the short and the long term in Pakistan, using the time series data for the period from 
1971 to 2009. It was found that school enrollment has a significantly positive impact on economic growth for both the short and the long term.

- The study by Khattak and Khan (2012) concentrated on the impact of education on the economic growth of Pakistan during 1971-2008. The study used "Johansen Cointegration test" and ordinary least squares (OLS) as analytical techniques for this purpose. The results from OLS showed that secondary education contributed significantly to the real GDP per capita in Pakistan. The primary education also positively affects economic growth, but the result is statistically insignificant. Another study about the same subject in Ethiopia, using aggregate data for the period 1980-1986, reported a contrary result that primary schooling tends to increase productivity, while secondary schooling has no effect (Mirotchie, 1994). Also, another study in India reported that primary education has a statistically significant impact on economic growth, whereas only limited evidence of the impact of secondary education on economic growth was observed (Self \& Grabowski, 2004).

Wang and Liu (2016) constructed a panel data model to examine the impact of education on economic growth, using data from 55 countries during the period from 1960 to 2009. The results of this study showed that, "in general, education has a significant positive impact on economic growth." Higher education has a significant positive effect on economic growth. Primary and secondary education also positively affects economic growth, but the results are statistically insignificant. Hanif and Arshed (2016) reported a similar result.

In the Arab countries, there are a few studies on this topic: two of these studies using panel data from Jordan to examine the relationship between education and economic growth were conducted by Bader (2012) and Khasawneh (2018). Bader (2012) examined the effect of education on economic growth in Jordan during the period from 1976 to 2007 using "Co-integration analysis." The main result of this study is that education positively affects economic growth in Jordan. Also, the study conducted by Khasawneh (2018) examined the relationship between economic growth and education in Jordan using the vector error correction model (VECM) during the period from 1960 to 2016 . However, the main results of this study is in contrast to the previous study, where it was concluded that there is a negative relationship between economic growth and education (gross enrollment rate), and that there is a negative relationship between economic growth and fertility rate. On the other hand, this study finds that there is a positive relationship between economic growth and literacy rate, government expenditures on education, inflation, life expectancy, and openness ratio.

Dahal and Nowak (2016) investigated the long-term relationship between education and economic growth in Nepal between 1995 and 2013 through the application of the "Johansen Cointegration test" and the OLS technique. The main results of this study using OLS show that secondary and higher education contribute positively and significantly to real GDP per capita in Nepal. Primary 
education also positively impacts economic growth, but the results are statistically less significant. The "cointegration test" results revealed the existence of a longterm relationship between education and real GDP per capita.

Several studies highlighted the importance of higher education in economic growth such as Wolff and Gittleman (1993), De Meulemeester and Rochat (1995), Bloom, Canning, and Chan (2006), Aziz, Khan, and Aziz (2008), Qazi, Raza, and Jawaid (2014). According to these authors, higher education plays a very important role in promoting economic growth, and that it can decrease knowledge gaps and reduce poverty. Wolff and Gittleman (1993) examined the correlation between higher education level and labor productivity index. They found that there is a high correlation between higher education enrollment ratio, labor productivity, and economic growth. De Meulemeester and Rochat (1995) tested the relationship between "the percentage of students enrolled in higher education and economic growth in six countries, namely: Australia, Italy, France, Japan, Sweden, and the United Kingdom. The results of this study indicated that there is a one-way relationship between higher education and economic growth in the short term in all of France, Japan, and Sweden, while there is a neutral relationship in both Australia and Italy." Bloom et al. (2006) showed that GDP has been significantly affected by higher education enrollment. They concluded that higher education can help African countries catch up and thus improve the potential for faster economic growth.

A study conducted by Aziz et al. (2008) examined the relationship between GDP and higher education in Pakistan. The study concluded that GDP is affected positively by higher education. This result is similar to that of Ali, Abdul-Hakim, and Abdullah (2016).

Another study conducted by Mariana (2015) explored the long-term association between Romanian higher education and economic growth for the period from 1980 to 2012. The main result of this study shows that higher education has a significantly positive influence on economic growth. This result is similar to the findings from Qazi et al. (2014).

Several studies such as Hill and King (1995), Barro (1996), Klasen (2002), Özpolat and Yildırım (2009) have showed that women's education has a positive effect on economic growth in all societies, especially in developing countries, by reducing fertility rate and increasing labor participation. Ainsworth, Beegle, and Nyamete (1996) examined the relationship between female schooling and cumulative fertility and contraceptive use in 14 sub-Saharan African countries. The main results showed that there is a statistically significant relationship between a lower fertility rate and an increase in human capital and economic growth, which means that increased women's education is linked to lower fertility. Similar results were found by Klasen (2002). Using panel data models, Ince (2011) studied the importance of women's education in Turkey's development. She indicated that education is a significant factor for economic progress, especially in Turkey.

El Alaoui (2016) examined if women's education affects economic growth using panel data from Morocco, Egypt, Tunisia, and Algeria during the period 
from 2000 to 2012. The main findings are that women's education, particularly tertiary education, women's labor force participation, and institutional capital affect economic growth positively. On the contrary, the primary and secondary school enrollment are negatively linked to economic growth. This study concludes that women's tertiary education is the main pillar for economic growth and sustainable development, in addition to the growth of a healthy and good-quality institutional capital. Also, the study by Bourguignon and Morrison (2002) examined how higher education levels lead to lower fertility rates by affecting per capita income growth and decreasing mortality rate per child, and the study by Barro (1991) indicated that more educated households are likely to have higher productivity than more children, which means that education and fertility rate have a negative effect on each other.

Using panel data from randomly selected Asia-Pacific countries, namely, Bangladesh, Cambodia, China, India, Indonesia, Lao People's Democratic Republic, Malaysia, Myanmar, Philippines, Thailand, and Vietnam, during the period between 1990 and 2010, Oztunc, Chi Oob, and Serin (2015) examined the extent to which women's education affected long-term economic growth in those countries. The study investigated the impact of female education on economic growth as measured by GDP, fertility, and the female labor force. Using panel regression analysis, the main findings are that the fertility rate, female labor force participation rate, and female primary school enrollment are significant factors.

A cross-sectional study by Barro and Salai-Martin (2003) examining the relationship between fertility rate and economic growth found that there is a strong negative relationship between educational attainment and fertility rate. Klasen and Lamanna (2009) also investigated the impact of gender inequality in education and employment on economic growth in developing countries during the period from 1960 to 2000 . They revealed that gender inequality in education and employment can reduce economic growth because women's education has a significant impact on fertility and the building of human capital.

Few studies examining the relationship between education and economic growth are available for Arab countries. For that reason, this study aims to investigate the relationship between economic growth and education (in general) and specifically women's education by choosing two countries, namely, Egypt and Jordan during the period from 1980 to 2016. The motivation behind choosing Egypt and Jordan was because these two Arab countries have many aspects in common, including religions, languages, values, and cultural norms. Also, they are similar in political and economic conditions, especially with regard to the experiences of wars such as the Arab-Israeli conflict and the depletion of resources. According to Human Development Indices 2018, Egypt and Jordan are developing countries (medium level), Egypt ranks 113 compared to Jordan's rank of 94 out of 189 countries.

Egypt and Jordan are two countries that give importance to the education sector for developing high-quality human capital, which has been the key to economic growth. However, rather unfortunately, Egypt and Jordan are not in 
a position to pursue developmental steps in education because of an increase in population and limited financial resources.

\section{Research Objectives}

The objectives of this study are to:

- Examine the relationship between education levels (primary education, secondary education, and higher education) and economic growth in Egypt and Jordan.

- Examine the relationship between female education levels (primary education, secondary education, and higher education) and economic growth in Egypt and Jordan.

- Identify the level of contribution of different levels of education to economic growth in Egypt and Jordan.

- Identify the level of contribution of different levels of female education to economic growth in Egypt and Jordan.

\section{Research Hypothesis}

The hypotheses based on these objectives are:

- $\mathrm{H}_{0(1)}$ : Primary education has a significant impact on economic growth in Egypt and Jordan.

- $\mathrm{H}_{0(2)}$ : Primary female education has a significant impact on economic growth in Egypt and Jordan.

- $\mathrm{H}_{0(3)}$ : Secondary education has a significant impact on economic growth in Egypt and Jordan.

- $\mathrm{H}_{\mathrm{O}(4)}$ : Secondary female education has a significant impact on economic growth in Egypt and Jordan.

- $\mathrm{H}_{0(5)}$ : Higher education has a significant impact on economic growth in Egypt and Jordan.

- $\mathrm{H}_{0(6)}$ : Higher female education has a significant impact on economic growth in Egypt and Jordan.

\section{Data Source and Methodology}

The study is based on time series data of Egypt and Jordan during the period from 1980 to 2016. Ten variables have been included in this study: one dependent variable that measures economic growth, namely, log GDP per capita; and nine independent variables, namely, total primary education enrollment rate, total secondary education enrollment rate, total higher education, total labor force participation rate, female primary education enrollment rate, female secondary education enrollment rate, female higher education enrollment rate, female labor 
force participation rate, and fertility rate (total births per woman). The data for these variables are taken from the World Bank Indicators (2018). The stationarity of data has been checked using four tests. These four tests were ADF-Fisher Chisquare test; Levin, Lin, and Chu test; PP-Fisher Chi-square test; and Im, Pesaran, and Shin W-test. "Non-stationary data might lead to some problems such as spurious regression, which gives incorrect results even if the regression is assumed to be stationary". For this reason, the panel unit root tests are used to check the stationarity of theses series.

This study uses annual time series data to study the impacts of education levels on economic growth. An OLS method has been used in the regression models to estimate the impact of different education levels [primary (total, females), secondary (total, females), and higher (total, females)] on the log GDP per capita (dependent variable). This study fits six regression models divided into two types of panel models: (1) the "total" panel models (three models) and (2) the "female" panel models (three models).

In the first model of the "total" panel models, each level of education is introduced. In the second model of the "total" panel models, each level of education and total labor force participation rate are introduced. In the third model of the "total" panel models, each level of education and fertility rate (births per woman) are introduced. The objective of each model was to test the hypotheses if these variables affect the economic growth.

In the first model of the "female" panel models, each level of female education is introduced. In the second model of "female" panel models, each level of female education and female labor force participation rate are introduced. In the third model of the "female" panel models, each level of female education and fertility rate (births per woman) are introduced. The objective of each model was to test the hypotheses, specifically if female education affects economic growth.

Estimation of model coefficients was facilitated by E-Views statistical package. The OLS regression model using time series data can take the following equations (Steigerwald, 1992):

$$
y_{i t}=\alpha+\beta^{\prime} X_{i t}+u_{i t} ; \quad i=1, \ldots, N ; t=1, \ldots, T,
$$

where:

$i$ is the individual dimension and $t$ is the time dimension.

\section{Statistical Analysis}

Economic growth is considered as one of the main objectives that all countries seek to accomplish. Economic growth depends on many indicators through investment, capital accumulation, and the increase in workforce, and it is measured by GDP, which has great significance because it expresses productivity of work and capital, and reflects their development. The GDP per capita (current US\$) is obtained by dividing GDP by the number of people in the country. A rise in per capita GDP and the growth rate of the real GDP (current US\$) signal growth 
in the economy, indicating an increase in productivity by controlling macroeconomic and demographic variables (see figures 1 and 2) that shows the trends of GDP per capita in Egypt and Jordan, 1980-2016, and the growth rate of real GDP in Egypt and Jordan, during 1980-2016, respectively.

To examine the impacts of education levels on economic growth, this study estimates six regression models divided into two types of panel models: (1) the "total" panel models (three models) and (2) the "female" panel models (three models). This study used student enrollment rate at primary (total, female), secondary (total, female), and higher level (total, female). Therefore, the impacts of education on the economic growth differ by education levels (total, female).

Before estimating the regression models, it is necessary to examine the time series properties of the data to make sure that all the variables included in these different models are stationary in order to have consistent results. The unit root hypothesis is tested using ADF-Fisher Chi-square test; Levin, Lin, and Chu test; PP-Fisher Chi-square test; and Im, Pesaran, and Shin W-test (Libanio, 2005).

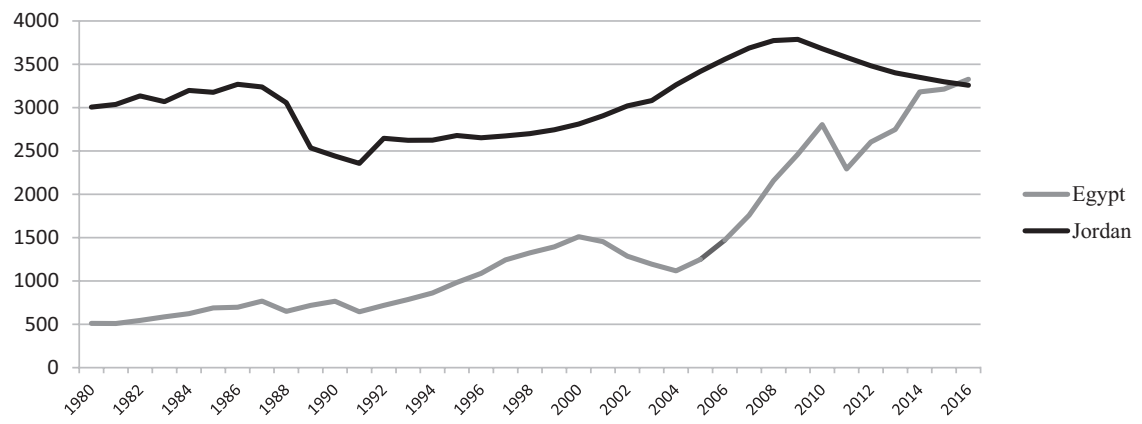

Figure 1 The trend of the real GDP per capita (current US\$) in Egypt and Jordan, 1980-2016.

Source: World Bank, World Development Indicators Online. Washington, DC: World Bank, 2018.

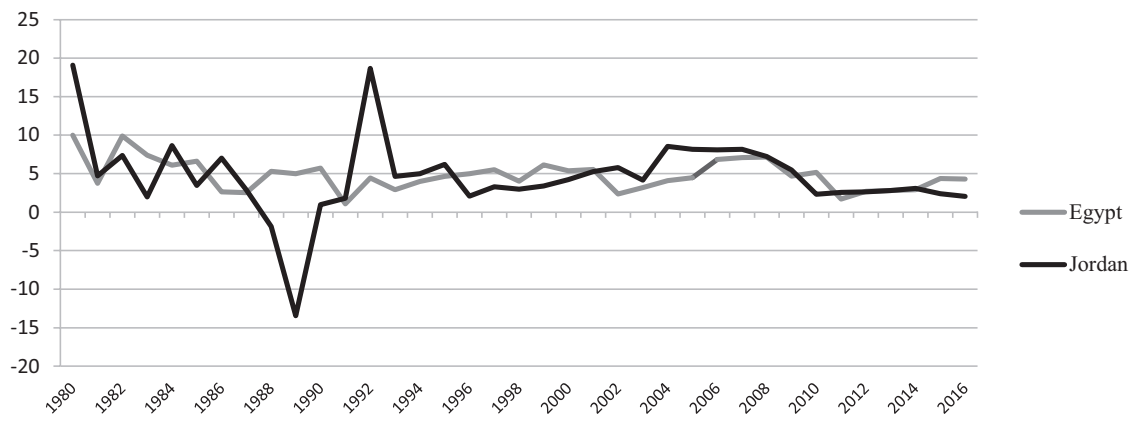

Figure 2 The trend of the growth rate of the real GDP per capita (current US\$) in Egypt and Jordan, 1980-2016.

Source: World Bank, World Development Indicators Online. Washington, DC: World Bank, 2018. 
For almost all the individual variables in level, student primary enrollment rate (total, female), student higher enrollment rate (total, female), labor force participation rate (total, female), log GDP per capita, used in this study, the null hypothesis of non-stationarity has been rejected at the 5 percent significance level (i.e. the majority of the variables are smooth, no unit root exists at level), while student secondary enrollment rate (total, female) are integrated to first different. Table 1 presents the results of these tests.

Table 2 shows the estimated regression coefficients of student enrollment rate (primary, secondary, and higher) on the log GDP controlling for macroeconomic variables (total labor force participation rate and female labor force participation rate) and demographic variable (fertility rate). The six regression models divided into two types of panel models, the "total" panel models (three models) and the "female" panel models (three models), are carried out based on the annual time series from 1980 to 2016. This study evaluates a fixed effect model to investigate the impact of education on economic growth in Egypt and Jordan.

Table 2 presents the results of the "total" panel models [model (1), model (2), and model (3)] and the "female" panel models [model (4), model (5), and model (6)].

Results of [model (1), model (2), and model (3)] show that primary education [student enrollment rate (primary, total)] and higher education [student enrollment rate (higher, total)] have significant positive effects on economic growth.

Table 1 Unit root tests

\begin{tabular}{|c|c|c|c|c|}
\hline Variables & $\begin{array}{l}\text { Levin, Lin, } \\
\text { and Chu test }\end{array}$ & $\begin{array}{c}\text { Im, Pesaran, } \\
\text { and Shin } \\
\text { W-test }\end{array}$ & $\begin{array}{c}\text { ADF-Fisher } \\
\text { Chi-square } \\
\text { test }\end{array}$ & $\begin{array}{c}\text { PP-Fisher } \\
\text { Chi-square } \\
\text { test }\end{array}$ \\
\hline $\begin{array}{l}\text { Student enrollment rate } \\
\text { (primary, total) }\end{array}$ & $-1.7885^{* *}$ & -1.5070 & 8.5378 & $19.646 * \star \star$ \\
\hline $\begin{array}{l}\text { Student enrollment rate } \\
\text { (primary, female) }\end{array}$ & $-7.1110 * * *$ & $-10.1827 * * *$ & $63.5280 * * *$ & $76.3787 * * *$ \\
\hline $\begin{array}{l}\text { Student enrollment rate } \\
\text { (secondary, total) }\end{array}$ & 0.2465 & 0.2688 & 2.1588 & $10.389 * *$ \\
\hline $\begin{array}{l}\text { Student enrollment rate } \\
\text { (secondary, female) }\end{array}$ & $-6.2419 * * *$ & $-6.2558 * * *$ & $38.6808 * * *$ & $68.1388 * * *$ \\
\hline $\begin{array}{l}\text { Student enrollment rate } \\
\text { (higher, total) }\end{array}$ & $-4.5652 * * *$ & $-4.9306 * * *$ & $29.2963 * * *$ & $64.5689 * * *$ \\
\hline $\begin{array}{l}\text { Student enrollment rate } \\
\text { (higher, female) }\end{array}$ & $-2.7884^{* * *}$ & $-6.4134 * * *$ & $39.6847 * * *$ & $67.5682 * * *$ \\
\hline $\begin{array}{l}\text { Total labor force } \\
\text { participation rate }\end{array}$ & 0.3698 & $-4.4383 * * *$ & $25.9481 * * *$ & $56.3660 * * *$ \\
\hline $\begin{array}{l}\text { Female labor force } \\
\text { participation rate }\end{array}$ & $2.3363 * * *$ & $-4.0249 * * *$ & $23.5756 * * *$ & $46.1664 * \star \star$ \\
\hline $\begin{array}{l}\text { Fertility rate } \\
\text { (births per woman) }\end{array}$ & $-6.0351 * * *$ & $-6.6138 * * *$ & $40.8179 * * *$ & 2.9196 \\
\hline Log GDP & 0.2405 & $-2.0463 * \star$ & 11.4961 ** & $43.6257 * * *$ \\
\hline
\end{tabular}

Source: Computed by the researcher.

Note: ${ }^{*}$ indicates a significant level of $5 \%, * * *$ indicates a significant level of $1 \%$. 
Table 2 Estimated regression coefficients of the "total" and "female" panel models (fixed effect model) in Egypt and Jordan, 1980-2016

\begin{tabular}{|c|c|c|c|c|c|c|}
\hline \multirow{2}{*}{$\begin{array}{l}\text { Independent } \\
\text { variables }\end{array}$} & \multicolumn{3}{|c|}{ "Total" panel models } & \multicolumn{3}{|c|}{ "Female" panel models } \\
\hline & Model (1) & Model (2) & Model (3) & Model (4) & Model (5) & Model (6) \\
\hline$\overline{\text { Constant }}$ & $\begin{array}{l}3.3066^{\star \star \star} \\
(6.530)\end{array}$ & $\begin{array}{l}1.3913 \\
(1.478)\end{array}$ & $\begin{array}{l}4.2042^{* * *} \\
(8.290)\end{array}$ & $\begin{array}{l}4.5612^{\star * \star} \\
(14.758)\end{array}$ & $\begin{array}{l}4.1249^{* * *} \\
(13.610)\end{array}$ & $\begin{array}{l}5.5436^{* \star *} \\
(12.964)\end{array}$ \\
\hline $\begin{array}{l}\text { Student enrollment } \\
\text { rate (primary, total) }\end{array}$ & $\begin{array}{l}0.0331 * * * \\
(5.376)\end{array}$ & $\begin{array}{l}0.0308 * * * \\
(5.262)\end{array}$ & $\begin{array}{l}0.0379 * * * \\
(6.911)\end{array}$ & - & - & - \\
\hline $\begin{array}{l}\text { Student enrollment } \\
\text { rate (primary, female) }\end{array}$ & - & - & - & $\begin{array}{l}0.0218 * * * \\
(5.992)\end{array}$ & $\begin{array}{l}0.0197 * * * \\
(6.065)\end{array}$ & $\begin{array}{l}0.0211 * * * \\
(6.477)\end{array}$ \\
\hline $\begin{array}{l}\text { Student enrollment } \\
\text { rate (secondary, total) }\end{array}$ & $\begin{array}{l}0.0050 \\
(0.929)\end{array}$ & $\begin{array}{l}-0.0012 \\
(-0.214)\end{array}$ & $\begin{array}{l}0.0032 \\
(0.686)\end{array}$ & - & - & - \\
\hline $\begin{array}{l}\text { Student enrollment } \\
\text { rate (secondary, } \\
\text { female) }\end{array}$ & - & - & - & $\begin{array}{l}0.0036 \\
(0.826)\end{array}$ & $\begin{array}{l}0.0036 \\
(0.921)\end{array}$ & $\begin{array}{l}0.0079 \\
(1.892)\end{array}$ \\
\hline $\begin{array}{l}\text { Student enrollment } \\
\text { rate (higher, total) }\end{array}$ & $\begin{array}{l}0.0217^{* *} \\
(2.444)\end{array}$ & $\begin{array}{l}0.0323 * * * \\
(3.414)\end{array}$ & $\begin{array}{l}0.0150 * * \\
(1.900)\end{array}$ & - & - & - \\
\hline $\begin{array}{l}\text { Student enrollment } \\
\text { rate (higher, female) }\end{array}$ & - & - & - & $\begin{array}{l}0.0221 * * * \\
(2.856)\end{array}$ & $\begin{array}{l}0.0113 \\
(1.487)\end{array}$ & $\begin{array}{l}0.0108 \\
(1.388)\end{array}$ \\
\hline $\begin{array}{l}\text { Total labor force } \\
\text { participation rate }\end{array}$ & - & $\begin{array}{l}0.0527 * * \\
(2.355)\end{array}$ & - & - & - & - \\
\hline $\begin{array}{l}\text { Female labor force } \\
\text { participation rate }\end{array}$ & - & - & - & - & $\begin{array}{l}0.0477 * * * \\
(3.237)\end{array}$ & - \\
\hline $\begin{array}{l}\text { Fertility rate } \\
\text { (births per woman) }\end{array}$ & - & - & $\begin{array}{l}-0.2368^{* *} \\
(-3.475)\end{array}$ & - & - & $\begin{array}{l}-0.2166^{* *} \\
(-3.009)\end{array}$ \\
\hline R-square & 0.9661 & 0.9713 & 0.9755 & 0.9675 & 0.9757 & 0.9748 \\
\hline Adjusted R-square & 0.9249 & 0.9342 & 0.9442 & 0.9279 & 0.9444 & 0.9424 \\
\hline F-statistics & 23.436 & 26.2389 & 31.0632 & 24.4443 & 31.1578 & 30.0611 \\
\hline Prob. (F-statistics) & 0.000 & 0.000 & 0.000 & 0.000 & 0.000 & 0.000 \\
\hline $\begin{array}{l}\text { Durbin-Watson } \\
\text { statistics }^{1}\end{array}$ & 1.3876 & 1.0883 & 1.5231 & 1.5969 & 1.5172 & 1.5265 \\
\hline
\end{tabular}

Source: Computed by the researcher.

Note: Dependent variable: Log GDP per capita. Figures in brackets are $t$-values.

${ }^{* *} p$-value $<0.05, * * * p$-value $<0.01$.

${ }^{1}$ The statistics that tests out-correlation in the residuals from a statistical regression, namely, the Durbin-Watson statistics, is always between 0 and 4 . A value of 2 means there is no out-correlation in the sample, 0 means negative out-correlation, and 4 means positive out-correlation.

Secondary education [student enrollment rate (secondary, total)] also positively affects economic growth, but the result is statistically insignificant. Several studies support these results (Afzal et al., 2010; Aziz et al., 2008; Bader, 2012; Bloom et al., 2006; De Meulemeester \& Rochat, 1995; Mariana, 2015; Qazi et al., 2014; Self \& Grabowski, 2004; Wang \& Liu, 2016; Wolff \& Gittleman, 1993).

Results from model 2 suggest that total labor force participation rate has the most significant positive impact on economic growth. This result is supported by the results of Khattak and Khan (2012) and Hanif and Arshed (2016). 
In addition, the results of model (3) indicate that there is a statistically significant negative relationship between fertility rate and economic growth. This result is supported by the results of Ainsworth et al. (1996) and Khasawneh (2018).

Results of [model (4), model (5), and model (6)] show that primary education [student enrollment rate (primary, female)] has a significant positive effect on economic growth. This result is similar as in Oztunc et al. (2015) but is opposite to the result of El Alaoui (2016). Secondary education [student enrollment rate (secondary, female)] also positively affects economic growth, but the result is statistically insignificant. In model (4), higher education [student enrollment rate (higher, female)] has a significant positive effect on economic growth. This result is similar as in El Alaoui (2016) but is opposite as in Oztunc et al. (2015). Higher education [student enrollment rate (higher, female)] is statistically insignificant in both models (5) and (6) after adding female labor force participation and fertility rate in model (5) and fertility in model (6) as control variables.

Also, the results of model (5) indicate that the female labor force participation rate is found to have the most significant positive impact on economic growth as well as the total labor force participation rate in model (2). This result is supported by the results of Oztunc et al. (2015) and El Alaoui (2016). In addition, the results of model (6) as in model (3) indicate that fertility rate has a significant negative impact on economic growth. This result is supported by the results of Barro and Salai-Marti (2003), Klasen and Lamanna (2009), and Oztunc et al. (2015).

According to the previous results of this study, the null hypotheses about the significant impact of primary and higher education on economic growth (total and female) in Egypt and Jordan, will be accepted. While the null hypotheses about the impact of secondary education (total and female) on economic growth in Egypt and Jordan will be rejected.

\section{Conclusion and Recommendations}

\section{Conclusion}

Education is a fundamental human right and a basic requirement for human development in the society. It is also very important for the development of any country and offers wide-ranging benefits to both individuals and societies. Education is key to empowering people and developing the economic, social, and personal well-being of all citizens in a society.

This study attempted to investigate the relationship between economic growth and education (in general), and specifically women's education choosing two countries, namely, Egypt and Jordan during the period from 1980 to 2016. The motivation behind choosing Egypt and Jordan was because these two Arab countries have many aspects in common, including religions, languages, values, and cultural norms. Also, they are similar in political and economic conditions, especially with regard to the suffering of wars in the Arab-Israeli conflict and the depletion of resources. According to Human Development Indices and Indicators 
2018, Egypt and Jordan are developing countries (medium level). Egypt ranks 113 compared to Jordan's rank of 94 out of 189 countries.

To examine the impacts of education levels on the economic growth, this study estimates six regression models divided into two types of panel models: (1) the "total" panel models (three models) and (2) the "female" panel models (three models) (as illustrated in the previous section, Data Source and Methodology). This study used student enrollment rate at primary (total, female), secondary (total, female), and higher levels (total, female). Therefore, the impacts of education on the economic growth differ by education levels (total, female).

For almost all the individual variables in level, student primary enrollment rate (total, female), student higher enrollment rate (total, female), labor force participation rate (total, female), log GDP per capita, used in this study, the null hypothesis of non-stationarity has been rejected at the 5 percent significance level (i.e., the majority of the variables are smooth, no unit root exists at level), while student secondary enrollment rate (total, female) are integrated to first different.

In light of the previous statistical analysis, this study found five significant results. First, the total primary education (total student enrollment rate) as well as female primary education (female enrollment rate) have a significant positive effect on economic growth. Second, the total higher education (student enrollment rate) as well as female higher education (female enrollment rate) have a significant positive effect on economic growth. Third, secondary education (student enrollment rate) also positively affects economic growth, but the result is statistically insignificant. Fourth, the female labor force participation rate is found to be the most important factor affecting economic growth as well as the total labor force participation rate. Higher level of education for all, specifically females, has increased labor force participation rate. Fifth, fertility rate is an important factor affecting economic growth.

According to the previous results of this study, the null hypotheses about the significant impact of primary and higher education on economic growth (total and female) in Egypt and Jordan, will be accepted. While the null hypotheses about the impact of secondary education (total and female) on economic growth in Egypt and Jordan will be rejected.

\section{Recommendations}

Based on the above main findings derived from this study, the following are important recommendations that could enhance economic growth in Egypt and Jordan:

1. Enhance educational opportunities to increase the enrollment rate, especially in female higher education by activating culture, social, and economic strategies, because "women with high education are more likely to educate their children, especially, their daughters” (Sandra, 2008). Moreover, females with high education have more opportunities to participate in the labor force, because they can use new technology better and 
have more innovative activity, which will enable them to contribute toward economic growth.

2. Encourage females to access reproductive health services for achieving the desired family size, leading to a decline in the population growth rate in the long term, which otherwise would be a big obstacle for economic growth.

3. Increased female participation in labor force is essential to enhance economic growth.

\section{References}

Abbas, Q., \& Foreman-Peck, J. (2008). Human capital and economic growth: Pakistan, 1960-2003. The Lahore Journal of Economics, 13(1), 1-27. doi: 10.35536/lje. 2008.v13. i1. a1

Afzal, M., Farooq, M., Ahmed, K., \& Begum, I. (2010). Relationship between school education and economic growth in Pakistan: ARDL bounds testing approach to cointegration. Pakistan Economic and Social Review, 48(1), 39-60.

Ainsworth, M., Beegle, K., \& Nyamete, A. (1996). The impact of women's schooling on fertility and contraceptive use: A study of fourteen sub-saharan African countries. The World Bank Economic Review, 10(1), 85-122. doi:10.1093/ wber/10.1.85

Ali, A., Abdul-Hakim, R., \& Abdullah, H. (2016). The relationships between higher education and economic growth in Pakistan. Journal of Management and Training for Industries, 3(2), 16-29. doi:10.12792/JMTI.3.2.16

Aziz, B., Khan, T., \& Aziz, S. (2008). Impact of higher education on economic growth of Pakistan. Journal of Social Sciences and Humanities, 6(2), 15-29.

Bader, F. M. (2012). The effect of education growth in Jordan: An econometric study (1976-2007) "the modified version." Administrative Sciences, 39(1), 281-290.

Barro, R. J. (1991). Economic growth in a cross section of countries. Quarterly Journal of Economics, 106(2), 407-443. doi:10.2307/2937943

Barro, R. J. (1996). Determinants of ec ${ }^{\mathrm{TM}}$ nomic growth: A cross-country empirical study. NBER Working Papers 5698, 1-118.

Barro, R. J. (2001). Human capital and growth. American Economic Review, American Economic Association, 91(2), 12-17. doi:10.1257/aer.91.2.12

Barro, R. J., \& Salai-Martin, X. I. (2003). Economic growth (2nd ed.). New York, NY: McGraw-Hill.

Becker, G. (1962). Investment in human capital: A theoretical analysis. Journal of Political Economy, 70, 9-49. doi:10.1086/258724

Bloom, D., Canning, D., \& Chan, K. (2006). Higher education and economic development in Africa. Harvard University, Human Development Sector Africa Region, 1-90.

Bourguignon, F., \& Morrison, C. (2002). The size distribution of income among world citizens, 1820-1990. American Economic Review, 92(4), 727-744. doi:10.1257/00028280260344443 
Dahal, G., \& Nowak, A. Z. (2016). The contribution of education to economic growth: Evidence from Nepal. International Journal of Economic Sciences, 5(2), $22-41$.

De Meulemeester, J., \& Rochat, D. (1995). A causality analysis of the link between higher education and economic development. Economics of Education Review, 14(4), 351-361. doi:10.1016/0272-7757(95)00015-C

El Alaoui, A. (2016). Impact of women's education on the economic growth: An empirical analysis applied to Morocco, Algeria, Tunisia, and Egypt. MPRA Paper 69787, University Library of Munich, Germany.

Gyimah-Brempong, K., Paddison, O., \& Mitiku, W. (2006). Higher education and economic growth in Africa. The Journal of Development Studies, 42(3), 509529. doi:10.1080/00220380600576490

Hanif, N., \& Arshed, N. (2016). Relationship between school education and economic growth: SAARC countries. International Journal of Economics and Financial Issues, 6(1), 294-300.

Hill, M. A., \& King, E. (1995). Women's education and economic well-being. Feminist Economics, 1(2), 21-46. doi:10.1080/714042230

Ince, M. (2011). The role of female education in economic development: A case for Turkey. Selçuk Üniversitesi Sosyal Bilimler Enstitüsü Dergisi, 26, 227-238.

Khasawneh, Q. M. (2018). The impact of education on economic growth in Jordan during (1960-2016). International Review of Management and Business Research, 7(1), 32-40. doi:10.30543/7-1(2018)-4

Khattak, U. R. N., \& Khan, J. (2012). The contribution of education to economic growth: Evidence from Pakistan. International Journal of Business and Social Science, 4(3), 145-151.

Klasen, S. (2002). Low schooling for girls, slower growth for all? Cross-country evidence on the effect of gender inequality in education on economic development. The World Bank Economic Review, 16(3), 345-373. doi:10.1093/wber/ lhfO04

Klasen, S., \& Lamanna, F. (2009). The impact of gender inequality in education and employment on economic growth: New evidence for a panel of countries. Feminist Economics, 15(3), 91-132. doi:10.1080/13545700902893106

Libanio, A. G. (2005). Unit roots in macroeconomic time series: Theory, implications, and evidence. Nova Economia, 15(3), 145-176. doi:10.1590/S010363512005000300006

Lucas, R. E. (1988). On the mechanics of economic development. Journal of Monetary Economics, 22, 3-42. doi:10.1016/0304-3932(88)90168-7.

Mariana, R. D. (2015). Education as a determinant of the economic growth. The Case of Romania. Social and Behavioral Sciences, 197, 404-412. doi: 10.1016/ j.sbspro.2015.07.156

Mirotchie, M. (1994). Technical efficiency of Ethiopian agriculture. In B. Abegaz (Ed.), Essays on Ethiopian economic development (pp. 87-158). Aldershot, UK: Avebury. 
Özpolat, A., \& Yıldırım, M. (2009). In developing countries, relationship between women's education and growth. Paper presented at Econanadolu 2009: Anadolu International Conference in Economics, Eskişehir, Turkey.

Oztunc, H., Chi Oo, Z., \& Serin, Z. V. (2015). Effects of female education on economic growth: A cross country empirical study educational sciences. Theory E Practice, 15(2), 349-357.

Qazi, W., Raza, S. A., \& Jawaid, S. T. (2014). Higher education and growth performance of Pakistan: Evidence from multivariate framework. Quality $\mathcal{E}$ Quantity, 48(3), 1651-1655. doi:10.1007/s11135-013-9866-9

Rahman, U. A., \& Salah, U. (2009). Statistical analysis of the different socioeconomic factors affecting the education of N-W.F. P (Pakistan). Journal of Applied Quantitative Methods, 4(1), 88-94.

Sandra, L. (2008). Women hold up half the sky. Global Economics Paper, Godman Sachs Economic Research, No. 164, 1-16.

Schultz, T. W. (1961). Investment in human capital. American Economic Review, $51,1-17$.

Self, S., \& Grabowski, R. (2004). Does education at all levels cause growth? India: A Case Study. Economics of Education Review, 23(1), 47-55. doi:10.1016/ S0272-7757(03)00045-1

Steigerwald, G. D. (1992). Adaptive estimation in time series regression models. Journal of Econometrics, 54, 251-275. doi:10.1016/0304-4076(92)90108-4

Wang, Y., \& Liu, S. (2016). Education, human capital and economic growth: Empirical research on 55 countries and regions (1960-2009). Theoretical Economics Letters, 6, 347-355. doi:10.4236/tel.2016.62039.

Wolff, E., \& Gittleman, M. (1993). The role of education in productivity convergence: Does higher education matter? In B. Van Ark \& D. Pilat (Eds.), Explaining economic growth (pp. 147-167). Elsevier Science Publishers.

World Bank. (2018). World development indicators online. Washington, DC: World Bank. Retrieved from http://data.worldbank.org/indicator 